\title{
Actualiteiten particuliere arbeidsongeschiktheidsverzekering (AOV)
}

\author{
Mr.dr. E.J. Wervelman*
}

\begin{abstract}
1. Inleiding
Deze bijdrage behandelt belangrijke actualiteiten op het terrein van particuliere arbeidsongeschiktheidsverzekeringen. Daarbij is in het bijzonder aandacht geschonken aan de rol van deze polis binnen de letselschade. Na een uiteenzetting van het karakter van arbeidsongeschiktheidsverzekeringen in paragraaf 2 spitsen de actualiteiten zich toe op het leerstuk van de voordeelsverrekening zoals bedoeld in artikel 6:100 BW. Aansluitend volgen in paragraaf 3 actualiteiten met betrekking tot de schending van de mededelingsplicht bij arbeidsongeschiktheidsverzekeringen, waarna in paragraaf 4 het begrip 'arbeidsongeschiktheid' wordt besproken. Paragraaf 5 tot slot ziet op bespreking van actualiteiten rondom de claimbehandeling van arbeidsongeschiktheidsverzekeringen. In paragraaf 6 volgt de afsluiting.
\end{abstract}

\section{Karakter van de \\ arbeidsongeschiktheidsverzekering: sommen- of schadeverzekering?}

Arbeidsongeschiktheidsverzekeringen zijn niet over één kam te scheren. Sommige polissen zijn sommenverzekeringen, waarbij het aldus onverschillig is of en in hoeverre met de uitkering schade wordt vergoed (art. 7:964 BW). Andere arbeidsongeschiktheidsverzekeringen daarentegen zijn schadeverzekeringen, omdat deze strekken tot vergoeding van vermogensschade die de verzekerde zou kunnen lijden (art. 7:944 BW). Het verschil tussen de beide varianten ligt met name in de rol van het inkomen, zowel in de totstandkomingsfase als gedurende de looptijd. ${ }^{1}$

Het karakter van arbeidsongeschiktheidsverzekeringen speelt een essentiële rol bij letselschade, indien het slachtoffer van de aansprakelijke partij verlies van arbeidsvermogen vordert. Heeft eenzelfde gebeurtenis voor de benadeelde naast schade

* Mr. dr. E.J. Wervelman is als advocaat verbonden aan VWW Advocaten - Mediation te Utrecht en is raadsheer-plaatsvervanger bij het gerechtshof's-Hertogenbosch.

1. Vgl. HR 3 oktober 2008, ECLI:NL:HR:2008:BD5828, NJ 2009/80, m.nt. Hartlief; HR 17 oktober 2008, ECLI:NL:HR:2008:BA0006; HR 6 juni 2003, ECLI:NL:HR:2003:AF6203, NJ 2004/670, m.nt. MMM; E.J. Wervelman, 'Kroniek van de particuliere arbeidsongeschiktheidsverzekering 2014-2019 (Deel 1)', AV $S$ 2019/25 (hierna: Wervelman: 2019a). tevens voordeel opgeleverd, dan moet, voor zover dit redelijk is, dit voordeel bij de vaststelling van de te vergoeden schade in rekening worden gebracht (art. 6:100 $\mathrm{BW}){ }^{2} \mathrm{Bij}$ letselschade mag ter vaststelling van de te vergoeden schade rekening worden gehouden met uitkeringen uit hoofde van arbeidsongeschiktheidsverzekeringen die inkomensschade vergoeden. Vooral uit wetshistorisch oogpunt is te bepleiten dat een uitkering uit hoofde van een arbeidsongeschiktheidsverzekering met een zodanig 'karakter' in mindering wordt gebracht op deze schadecomponent. Eerder betoogde ik dat daarin naar mijn overtuiging dan ook direct wel de begrenzing van de mogelijkheden tot verrekening in de zin van artikel 6:100 BW ligt. ${ }^{3}$ In die zin dat dergelijke uitkeringen niet mogen worden verrekend, indien het 'onverschillig is of en in hoeverre met de uitkering schade wordt vergoed', zoals artikel 7:964 BW de sommenverzekering omschrijft. Dat geldt bijvoorbeeld voor ongevallenverzekeringen, maar ook voor diverse in omloop zijnde particuliere arbeidsongeschiktheidsverzekeringen. Weliswaar is de hoogte van het inkomen bij het aangaan van vele particuliere arbeidsongeschiktheidsverzekeringen in zekere zin een richtsnoer ter bepaling van de hoogte van de verzekerde bedragen, maar meer ook echt niet. Ik heb in 2010 betoogd dat het in dergelijke situaties dan ook ten zeerste de vraag is of men wel toekomt aan de voor de voordeelsverrekening noodzakelijke eis van inkomensvervanging. ${ }^{4}$

Niet alleen de actuele jurisprudentie, maar ook die sinds het arrest dat de Hoge Raad wees op 1 oktober $2010^{5}$ is nog steeds bepaald casuistisch te noemen. Bij beschikking van 1 mei

2. Vgl. omtrent voordeelstoerekening ook P.J. Tanja, 'Roermondse gastronomie en de dubbele causaliteitsmaatstaf van voordeelstoerekening', $B b$ 2018/67; R.J. Tjittes, 'Vernieuwde voordeelstoerekening', RMThemis 2017, afl. 2, p. 41-42; Asser/Sieburgh 6-II 2017/157; T. Hartlief, 'Voordeelstoerekening anno 2017', $A A$ 2017, p. 473-487; S.S.Y. Engelen \& A.L.M. Keirse, 'Voordeelstoerekening: leuker kunnen we het niet maken, wel inzichtelijker', TVP 2017, p. 29-41; J.W. Silvius, 'Voordeelstoerekening volgens het arrest Verhaeg/Jenniskens: duidelijkheid of debat?', AVßS 2017/3.

3. Vgl. E.J. Wervelman, 'Voordeelsverrekening bij letselschade van uitkeringen uit hoofde van particuliere arbeidsongeschiktheidsverzekeringen', TVP 2010, p. 16.

4. Vgl. Wervelman 2010, p. 16.

5. HR 1 oktober 2010, ECLI:NL:HR:2010:BM7808, NJ 2013/81, m.nt. Hartlief. 
$2018^{6}$ betitelde het gerechtshof Arnhem-Leeuwarden de arbeidsongeschiktheidsverzekering die de inzet vormde van een deelgeschil als schadeverzekering. De verzekering had tot doel om uitkering te verlenen bij derving van inkomen ten gevolge van arbeidsongeschiktheid. Het te verzekeren bedrag was gebaseerd op het gemiddelde inkomen in de drie jaar voorafgaand aan het afsluiten van de verzekering. Maximaal verzekerd was $90 \%$ van het gemiddeld inkomen, waarbij de verzekering een optierecht kende tot een maximale verhoging van $20 \%$ van de verzekerde jaarrente. De polisvoorwaarden bevatten een taakverschuivingsclausule, waardoor bij de claimbehandeling aanpassingen van werkzaamheden en werkomstandigheden en taakverschuivingen binnen het eigen bedrijf werden betrokken. De polis kende voorts een regeling met betrekking tot de duiding van passende arbeid in geval van arbeidsongeschiktheid en verplichtte verzekerden voorts om al het mogelijke te doen om hun herstel te bevorderen. Daartoe bestond tevens de verplichting tot het doorvoeren van aanpassingen binnen het bedrijf die in redelijkheid konden worden verlangd om het herstel te bevorderen en de arbeidsongeschiktheid te verminderen. Uit deze en enkele wat minder in het oog springende feiten leidde het hof af dat tussen partijen een schadeverzekering was overeengekomen. Daarbij tekende het hof aan dat de verzekering tot doel had om een periodieke uitkering te verlenen ter compensatie van inkomstenderving. Daarbij kon de hoogte van de uitkering wijzigen of eindigen als de arbeidsongeschiktheid wijzigde of eindigde. De verzekering diende aldus ter vergoeding van de door verzekerde geleden inkomensschade. Daaraan deed niet af dat de verzekering niet de feitelijke schade dekte. Evenmin deed daaraan af de stelling van de verzekerde dat hij persoonlijk een andere bedoeling had gehad met het afsluiten van de verzekering, te weten om niet een terugval in de inkomsten op te vangen, maar om zijn zakelijke vermogen te beschermen bij arbeidsongeschiktheid.

In de recente kroniek van de arbeidsongeschiktheidsverzekering heb ik mij afgevraagd of de Hoge Raad het oordeel van het hof intact zou hebben gelaten als daar cassatie tegen zou zijn ingesteld, omdat de beide casus erg dicht aanliggen tegen de casus die leidden tot de arresten van de Hoge Raad uit

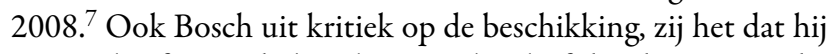
moeite heeft met de bepaling van het hof dat de premies die het slachtoffer heeft betaald voor de arbeidsongeschiktheidsverzekering over de volle looptijd van de verzekering in mindering moeten worden gebracht. ${ }^{8}$ Eerder stelde ik mij op het standpunt dat ik mij in algehele terugbetaling van de in veel gevallen vaak jarenlang betaalde premie niet kan vinden, en ik stel voor om uit te gaan van een jaarpremierestitutie. ${ }^{9}$

6. Hof Arnhem-Leeuwarden 1 mei 2018, ECLI:NL:GHARL:2018:4122.

7. Vgl. Wervelman 2019.

8. Vgl. E.W. Bosch, 'Voordeelstoerekening van AOV-uitkeringen in letselzaken', VR 2020/43.

9. Wervelman 2010, p. 15; Rb. Arnhem 7 juni 2006, ECLI:NL:RBARN: 2006:AY0497.
De literatuur heeft verzet aangetekend tegen verrekening. Op zichzelf is dat wel te begrijpen, maar ik mis in de discussie steeds dat bij beantwoording van de vraag of verrekening van uitkeringen uit hoofde van arbeidsongeschiktheidsverzekeringen op zijn plaats is als 'factor van bijzonder gewicht' de mate waarin de betrokken sommenverzekering voorziet in de periodieke uitkering ter compensatie van inkomstenderving. ${ }^{10}$ Hartlief wijst er niet voor niets in zijn noot onder het arrest van de Hoge Raad van 1 oktober 2010 op dat de meest reële uitzondering van toerekening van uitkeringen uit sommenverzekeringen wordt gevormd door de verzekering die aanleiding geeft tot periodieke uitkeringen, die weliswaar strekken tot vergoeding van inkomensschade. Over de wijze waarop inkomensschade moet worden beoordeeld, bepalen de polisvoorwaarden niets. Het is van groot belang om dat te onderkennen, omdat de 'doelbepaling' in vrijwel alle arbeidsongeschiktheidsverzekeringen (ook in sommenverzekeringen) voorkomt. In die zin dat vrijwel standaard is bepaald dat de verzekering 'strekt tot het doen van uitkeringen bij arbeidsongeschiktheid ingeval van derving van inkomen door de verzekerde' of woorden van gelijke strekking. Wat volgens Hartlief dan 'overheerst en ook zwaarder weegt' dan het feit dat de aansprakelijkheidsverzekeraar van toerekening profiteert, is het idee dat voorkomen moet worden dat benadeelde twee keer een vergoeding van dezelfde schade ontvangt. Ik ben en blijf dat met hem eens. In mijn noot onder de beschikking van de rechtbank Den Haag van 24 maart $2015^{11}$ heb ik ook aangegeven dat dat uit macro-economisch opzicht niet verantwoord is. Het is onnodig kostbaar, omdat dezelfde schade dan twee keer is verzekerd. Bovendien komt de benadeelde in een duidelijk voordeliger positie, wat in strijd is met het indemniteitsbeginsel. Vanzelfsprekend realiseer ik mij dat het gaat om een sommenverzekering, maar dat neemt de knellende dogmatiek uit verzekeringsrechtelijk oogpunt niet weg. ${ }^{12}$

Bespreking verdient in dit verband ook de beschikking van de rechtbank Rotterdam van 21 november 2018. ${ }^{13}$ In deze beschikking verrekende de rechtbank de AOV-uitkering voor $50 \%$. Alhoewel niet goed is na te gaan op grond waarvan de rechtbank precies tot dit percentage heeft besloten, spreekt mij aan dat de rechtbank - als eerste in Nederland - haar nek heeft durven uitsteken en zich heeft willen wagen aan een specifieker oordeel over het percentage. Tot deze beschikking gaat de gehele jurisprudentie uit van een 'alles of niets'-situatie. Ik heb eerder verwoord dat ik dat onbevredigend acht. ${ }^{14}$ Niet in de laatste plaats ook omdat het gaat om een redelijkheidsoordeel. En bij het uitspreken van een redelijkheidsoordeel over eigen schuld in de zin van artikel 6:101 BW schuwt de

10. Vgl. A-G Wuisman in 2.2.4 van zijn conclusie voor HR 1 oktober 2010, ECLI:NL:HR:2010:BM7808, NJ 2013/81, m.nt. Hartlief.

11. Rb. Den Haag 24 maart 2015, JA 2015/100.

12. Vgl. E.J. Wervelman, noot onder Rb. Limburg 6 december 2017 , ECLI:NL:RBLIM:2017:12135,JA 2018/54.

13. Rb. Rotterdam 21 november 2018, ECLI:NL:RBROT:2018:8874, JA 2019/15, m.nt. E.W. Bosch.

14. E.J. Wervelman, noot onder Rb. Limburg 6 december 2017, ECLI:NL:RBLIM:2017:12135, JA 2018/54 
rechter niet om zich uit te spreken in percentages van 25, 50 of $75 \%$; bij oordelen over voordeelsverrekening uit hoofde van artikel 6:100 BW daarentegen kwam de rechter helaas niet verder dan een karig onderscheid tussen 0 en $100 \%$.

Partijen dienen zich overigens bij de afwikkeling van letselschades waar het leerstuk van voordeelsverrekening een rol van betekenis speelt, terdege te realiseren dat zij alle feiten en achtergronden met betrekking tot de in het geding zijnde arbeidsongeschiktheidsverzekering over het voetlicht moeten brengen. Dat ging mis in de procedure die leidde tot het vonnis van de rechtbank Gelderland van 20 februari 2019. ${ }^{15}$ Daar had de aansprakelijkheidsverzekeraar naar het oordeel van de rechtbank onvoldoende argumenten over het voetlicht gebracht om tot verrekening te kunnen komen. Terecht wijst de rechtbank erop dat de Hoge Raad in zijn arrest van 1 oktober $2010^{16}$ voor verrekening in geval van een sommenverzekering vereist dat de aansprakelijkheidsverzekeraar argumenten aandraagt waarom het niettemin redelijk is om te verrekenen. Ik wijs er daarbij op dat het niet alleen gaat om een inhoudelijke discussie over de toepasselijke polisvoorwaarden die aldus in het geding moeten worden gebracht, maar ook om overlegging van het polisblad dat van toepassing is op de arbeidsongeschiktheidsclaim. Bovendien moeten partijen de rechter inzicht geven in alle feiten en achtergronden ten tijde van de totstandkoming van de arbeidsongeschiktheidsverzekering. Daarmee wordt aldus overlegging van het integrale acceptatiedossier onmisbaar. Om te kunnen achterhalen of, en zo ja, in hoeverre de arbeidsongeschiktheidsverzekeraar tijdens de looptijd interesse heeft getoond in de hoogte van het inkomen, is voorts relevant dat partijen de rechter ook daarover informeren door opgave van jaarlijkse navraag naar het inkomen of andere vormen van contact.

\section{Aangaan van}

\section{arbeidsongeschiktheidsverzekeringen}

De problematiek rondom het aangaan van arbeidsongeschiktheidsverzekeringen kenmerkt zich niet alleen door procedures met betrekking tot schending van de mededelingsplicht in het kader van de artikelen 7:928-930 BW. Van belang is tevens de Wet op de medische keuringen (WMK), die sinds 1 januari 1998 het vraagrecht van verzekeraar drastisch heeft ingeperkt. Met de inwerkingtreding van de Wet gelijke behandeling op grond van handicap of chronische ziekte (WGBH/CZ) ten aanzien van arbeidsongeschiktheidsverzekeringen verdient ook dit aspect aandacht in het kader van deze bijdrage.

De beslissing van 10 januari $2020^{17}$ van het College voor de Rechten van de Mens is het eerste oordeel over arbeidsongeschiktheidsverzekeringen in het kader van de WGBH/CZ en verdient aldus bespreking. Het College voor de Rechten van de Mens oordeelde over het verzoek van een aspirant-verzeke-

15. Rb. Gelderland 20 februari 2019, ECLI:NL:RBGEL:2019:665.

16. HR 1 oktober 2010, ECLI:NL:HR:2010:BM7808, NJ 2013/81, m.nt. Hartlief.

17. CRM 10 januari 2020, 2020-1. ringnemer om te beoordelen of de arbeidsongeschiktheidsverzekeraar jegens haar verboden onderscheid op grond van handicap of chronische ziekte had gemaakt doordat één van haar medisch adviseurs voornemens was om een negatief advies uit te brengen inzake haar aanvraag voor een arbeidsongeschiktheidsverzekering. Betrokkene had sinds 2001 een torticollis spasmodica. Dat is een neurologische aandoening waarbij het hoofd een dwangstand kan innemen en niet vrij kan worden bewogen. Betrokkene wilde bij de arbeidsongeschiktheidsverzekeraar een arbeidsongeschiktheidsverzekering afsluiten, omdat zij vanaf 2018 startte als zelfstandig consultant/auditor. Zoals gebruikelijk beoordeelde de medisch adviseur het aldus ter verzekering aangeboden risico. De medisch adviseur liet betrokkene weten dat zij voornemens was om te adviseren haar geen verzekering aan te bieden. Betrokkene maakte gebruik van haar blokkeringsrecht, waardoor het advies niet werd doorgestuurd aan de arbeidsongeschiktheidsverzekeraar. Betrokkene trok bovendien haar aanvraag tot het aangaan van de arbeidsongeschiktheidsverzekering in. Betrokkene nam met het voorgenomen advies geen genoegen en diende een klacht in bij het College voor de Rechten van de Mens. De arbeidsongeschiktheidsverzekeraar voerde verweer door erop te wijzen dat hij geen beslissing had genomen vanwege het beroep op het blokkeringsrecht en de ingetrokken aanvraag. Dat betoog verwierp het College door erop te wijzen dat reeds eerder was geoordeeld dat natuurlijke en rechtspersonen die goederen en diensten aanbieden of toegang daartoe verlenen, aangesproken kunnen worden door personen die menen dat er in hun nadeel onderscheid is of wordt gemaakt. Ook zonder dat concreet een overeenkomst is gesloten of een aanvraag daartoe is gedaan. De wettelijke bescherming beperkt zich volgens het College voor de Rechten van de Mens dus niet tot situaties waarin een formele of definitieve beslissing op een aanvraag voor verzekering is genomen. ${ }^{18}$

Het College vervolgt dat het erom gaat of in de fase van de medische acceptatie verboden onderscheid is gemaakt op grond van handicap of chronische ziekte. Dat is volgens het College niet het geval, omdat betrokkene er niet in is geslaagd feiten aan te voeren die onderscheid op grond van handicap of chronische ziekte kunnen doen vermoeden. Betrokkene had verklaard dat de gegevens die waren opgenomen in het medisch advies van de medisch adviseur op zichzelf allemaal juist zijn. $\mathrm{Zij}$ wist dat de medisch adviseur daarover nadere informatie zou inwinnen bij haar behandelaars, want daarvoor was haar toestemming gevraagd. Het inwinnen van deze informatie is derhalve op een transparante wijze geschied en het advies is gebaseerd op correcte medische gegevens. In die zin is het advies volgens het College op een controleerbare en systematische wijze tot stand gekomen. Betrokkene verklaarde ook dat haar probleem met het medisch advies alleen zit in de conclusie van de medisch adviseur. Die conclusie doet volgens haar geen recht aan het gegeven dat de klachten die uit torticollis kunnen voortvloeien zich bij haar al vele jaren niet of nau-

18. Vgl. CGB 3 mei 2005, 2005-80; CGB 13 oktober 2005, ECLI:NL:XX: 2005:BM2832. 
welijks voordoen. Het College constateert evenwel dat de medisch adviseur schriftelijk had uitgelegd waarom zij tot haar conclusie was gekomen door uit te leggen dat het erom gaat dat bij personen die een torticollis hebben zich frequent klachten voordoen die tot arbeidsongeschiktheid leiden. De medisch adviseur gaat uit van het risico op groepsniveau (risicocohorten) en kijkt niet naar het risico van de eventuele afwijkende mate van gezondheidsklachten op individueel niveau. Ook op dat punt waren de procedure en de daarover verstrekte uitleg inzichtelijk geweest volgens het College voor de Rechten van de Mens. De arbeidsongeschiktheidsverzekeraar had naar diens oordeel dan ook geen verboden onderscheid gemaakt op grond van handicap of chronische ziekte.

Er wordt (ook) zelden geprocedeerd over de WMK. Deze wet vindt toepassing bij het aangaan van arbeidsongeschiktheidsverzekeringen. Het arrest van het gerechtshof Amsterdam van 9 juli $2019^{19}$ verdient aldus bespreking. Inzet van het geschil vormde een semicollectieve arbeidsongeschiktheidsverzekering die facultatief aan een deelnemer werd aangeboden. De werknemer diende ruim vier jaar na zijn indiensttreding bij de werkgever een aanvraag in om te worden toegelaten tot de arbeidsongeschiktheidsverzekering. Verzekeraar wenste nadere medische informatie te ontvangen om de aanvraag deugdelijk te kunnen beoordelen. Werknemer gaf gehoor aan dit verzoek en vulde een gezondheidsverklaring in. Verzekeraar liet daarop weten dat hij de verzekering wel met hem wilde aangaan, maar onder toepassing van enkele uitsluitingsclausules. Verzekerde was het daarmee niet eens en beriep zich op het keuringsverbod van artikel 4 lid 4 WMK. Rechtbank en hof waren dat niet met hem eens. Werknemer had immers pas ruim vier jaar na zijn indiensttreding de aanvullende arbeidsongeschiktheidsverzekering aangevraagd die hem facultatief was aangeboden. Uit de WMK, de ratio en de parlementaire geschiedenis en het Van Leeuwen Convenant volgt volgens het hof dat het keuringsverbod alleen geldt voor aanvullende arbeidsongeschiktheidsverzekeringen die aan de burgerrechtelijke arbeidsverhouding of in verband met een aanstelling in openbare dienst zijn verbonden. Het Van Leeuwen Convenant bepaalt meer specifiek dat het keuringsverbod geldt voor verzekeringen voor werknemers die op grond van de arbeidsovereenkomst door werkgever worden gesloten, en eveneens voor verzekeringen waarbij deelname op vrijwillige basis plaatsvindt, indien de werknemer een beslissing neemt binnen drie maanden na de eerste dag van indiensttreding op de ingangsdatum van de verzekering tussen de werkgever en de verzekeraar. De WMK en het Van Leeuwen Convenant hebben als strekking om verkapte keuringen te voorkomen. Dit speelt in dit geval niet, omdat de aanvraag pas geruime tijd na indiensttreding is gedaan. Het risico van belemmering bij toegang tot de arbeid en voorzieningen inzake de oude dag en invaliditeit doet zich volgens het hof dan ook niet voor, omdat op het moment van de aanvraag van de verzekering in de situatie van de werknemer geen sprake was van arbeidsmobiliteit.

19. Hof Amsterdam 9 juli 2019, ECLI:NL:GHAMS:2019:2395, JA 2019/161; RAV 2020/5
Laat staan van belemmeringen daarvan. Anders gezegd is een keuring na vier jaar toegestaan.

Er bestaat (wel) veel - actuele - jurisprudentie rondom de schending van de mededelingsplicht bij arbeidsongeschiktheidsverzekeringen. Ingevolge artikel 7:928 BW is de verzekeringnemer kort gezegd verplicht om de verzekeraar voor het sluiten van de overeenkomst alle feiten mee te delen die hij kent of behoort te kennen en waarvan hij weet of behoort te begrijpen dat de beslissing van de verzekeraar of, en zo ja, op welke voorwaarden, hij de verzekering zou willen afsluiten, afhangt of kan afhangen. De wet verankert hiermee de vereisten van kennis, kenbaarheid, relevantie en verschoonbaarheid. $^{20}$

Arbeidsongeschiktheidsverzekeringen worden doorgaans afgesloten op de grondslag van de door de verzekeraar opgestelde vragenlijst. Een ondertekende gezondheidsverklaring is een onderhandse akte die tussen partijen dwingend bewijs oplevert. ${ }^{21}$ De verzekeraar kan zich er dan niet op beroepen dat de vragen niet zijn beantwoord of feiten waarnaar niet is gevraagd niet zijn meegedeeld, en evenmin dat een in algemene termen vervatte vraag onvolledig is beantwoord, tenzij is gehandeld met het opzet om de verzekeraar te misleiden. Dat blijkt uit artikel 7:928 lid 6 BW.

Nabestaanden van een door een misdrijf om het leven gekomen verzekerde haalden bakzeil bij het gerechtshof 's-Hertogenbosch op 14 april $2020 .^{22}$ De verzekeringnemer had desgevraagd ingevuld dat zijn jaarinkomen over 2012 en 2013 $€ 45.000$ respectievelijk $€ 47.000$ bruto per jaar bedroeg. Voorts had hij als beroep in het aanvraagformulier opgegeven 'manager restaurant'. De overlijdensrisicoverzekering was tot stand gekomen met een verzekerd kapitaal van $€ 500.000$. De verzekeraar stelde naar aanleiding van het overlijden van de verzekerde en de aanspraak op het verzekerde bedrag door de nabestaanden een onderzoek in. Daaruit bleek dat verzekerde ten tijde van de aanvraag van de verzekering geen manager van een restaurant was. Evenmin had hij de opgegeven inkomens verdiend. Het hof was dan ook van oordeel dat het aanvraagformulier onjuist was ingevuld. Dat had tot gevolg dat geen verzekering tot stand zou zijn gekomen bij kennis van de ware stand van zaken. Temeer ook daar tussen partijen niet in discussie was dat als verzekerde melding zou hebben gemaakt van het feit dat hij zijn inkomen zou verwerven met criminele

20. Vgl. Asser/Wansink, Van Tiggele \& Salomons 7-IX* 2019/139-178; Wervelman 2019.

21. Vgl. Rb. Gelderland 21 februari 2018, ECLI:NL:RBGEL:2018:765.

22. Hof's-Hertogenbosch 14 april 2020, ECLI:NL:GHSHE:2020:1265. 
activiteiten, verzekeraar niet tot het sluiten van de verzekering zou zijn overgegaan. ${ }^{23}$

Bij beslissing van 31 januari $2020^{24}$ verwierp de Geschillencommissie Financiële Dienstverlening de klacht die was ingediend tegen een arbeidsongeschiktheidsverzekeraar die een ter verzekering aangeboden risico bij kennis van de ware stand van zaken zou hebben aanvaard met een clausule rug, met recht op herbeoordeling na vijf jaar. De cafetariahouder die de verzekering wilde afsluiten, was, naar achteraf bleek, diverse keren behandeld door een fysiotherapeut, maar had dat niet opgegeven in de gezondheidsverklaring. Ten onrechte, aldus de Geschillencommissie, die aan de hand van de GAVrichtlijnen bij een rugbelastend beroep als dat van de cafetariahouder de voorgestelde clausule terecht achtte. De beslissing van de Geschillencommissie heeft geleid tot Kamervragen van de SP. ${ }^{25}$

Het relevantievereiste speelde ook een grote rol in de zaak die leidde tot het arrest van de Hoge Raad van 5 oktober 2018 . $^{26}$ In de casus stond op zichzelf tussen partijen wel vast dat de verzekerde zijn mededelingsplicht had geschonden. Inzet van het geding vormde vooral het antwoord op de vraag of, en zo ja, in hoeverre de verzekeraar het ter verzekering aangeboden risico bij bekendheid met de ware stand van zaken zou zijn aangegaan. Bij het beantwoorden van die vraag moet volgens de Hoge Raad niet geheel of gedeeltelijk worden geabstraheerd van de concrete acceptatiecriteria van de desbetreffende verzekeraar. Een beroep op artikel 7:930 lid 4 BW zal in beginsel alleen kunnen slagen indien de verzekeraar aantoont dat een redelijk handelend verzekeraar bij bekendheid met de ware stand van zaken de verzekering niet zou hebben gesloten, aldus de Hoge Raad. Hij vervolgt:

'Dat een verzekeringnemer die zijn mededelingsplicht niet nakomt daarvan de gevolgen ondervindt die een redelijk handelend verzekeraar daaraan niet zou verbinden, is alleen dan aanvaardbaar als de verzekeringnemer wist of behoorde te begrijpen welk acceptatiebeleid de verzekeraar hanteerde. Dan kon hij immers de relevantie van de nietmedegedeelde feiten of omstandigheden binnen dat acceptatiebeleid overzien. In een dergelijk geval geldt naast de eis dat de verzekeringnemer op de hoogte was of moest zijn van het acceptatiebeleid niet ook de eis dat de verzeke-

23. Zie voor een ander voorbeeld waarin een redelijk handelend verzekeraar bij kennis van de ware stand van zaken geen arbeidsongeschiktheidsverzekering zou hebben afgesloten, de beslissing van de Geschillencommissie van het Kifid van 5 december 2019, 2019-1006. Zie voor een casus waarin bij kennis van de ware stand van zaken een uitsluitingsclausule zou zijn opgenomen: Rb. Gelderland 22 maart 2019, ECLI:NL:RBGEL: 2019:1761 en Geschillencommissie Kifid 26 augustus 2020, 2020-671.

24. Geschillencommissie Kifid 31 januari 2020, 2020-88.

25. Kamervraag 2020Z03393; Aanhangsel Handelingen II 2019/20, nr. 1999, p. 1-4.

26. HR 5 oktober 2018, ECLI:NL:HR:2018:1841. Zie omtrent de redelijk handelend verzekeraar ook Hof Den Haag 11 december 2018, ECLI:NL:GHDHA:2018:3965; Hof 's-Hertogenbosch 4 december 2018, ECLI:NL:GHSHE:2018:5010. ringnemer bij het aangaan van de verzekering wist dat het acceptatiebeleid van zijn verzekeraar afweek van dat van een redelijk handelend verzekeraar. De noodzaak die wetenschap te verlangen volgt niet uit de genoemde bepalingen.'

Bij het beantwoorden van de vraag wat een redelijk handelend verzekeraar bij kennis van de ware stand van zaken zou hebben gedaan, kan groot gewicht toekomen aan het acceptatiebeleid van andere verzekeraars. De Hoge Raad acht echter niet uitgesloten dat als het beleid van een of meer andere verzekeraars op inhoudelijke gronden de toets aan de maatstaf van een redelijk handelend verzekeraar niet kan doorstaan, daarop geen beroep kan worden gedaan. Evenmin acht de Hoge Raad uitgesloten dat het acceptatiebeleid van de betrokken verzekeraar op inhoudelijke gronden blijkt te voldoen aan de maatstaf van een redelijk handelend verzekeraar. Ook al voeren andere verzekeraars een ander (of geen) beleid. Het beredeneerde betoog van een verzekeraar dat een redelijk handelend verzekeraar bij kennis van de ware stand van zaken de verzekering niet zou hebben gesloten, kan - afhankelijk van de door de verzekeraar aangevoerde argumenten en omstandigheden van het geval - tot het oordeel leiden dat een redelijk handelend verzekeraar de verzekering in dat geval niet zou zijn aangegaan. Voor dat oordeel acht de Hoge Raad niet steeds noodzakelijk dat het acceptatiebeleid van andere verzekeraars wordt onderzocht. Nee, het zal van het verweer van de verzekeringnemer afhangen of het acceptatiebeleid van andere verzekeraars in de beoordeling moet worden betrokken. ${ }^{27}$

De Hoge Raad vernietigde het arrest van het hof en verwees de zaak door naar het gerechtshof Den Haag voor verdere behandeling. In het vervolgarrest van 18 augustus $2020^{28}$ ging het na verwijzing door de Hoge Raad (nog slechts) om de vraag of, en zo ja, op welke voorwaarden een redelijk handelend verzekeraar bij de juiste kennis van zaken een arbeidsongeschiktheidsverzekering zou hebben afgesloten. Het hof was van oordeel dat verzekeraar zijn standpunt voldoende had gemotiveerd en onderbouwd door verwijzing naar de reactie van vijf medisch adviseurs met de vraag hoe hun acceptatieadvies zou hebben geluid bij kennis van de ware stand van zaken. Het hof wees de vorderingen van verzekerde dan ook af.

Met inachtneming van het arrest van de Hoge Raad van 5 oktober $2018^{29}$ overwoog de Geschillencommissie van het Klachteninstituut Financiële Dienstverlening (Kifid) bij beslissing van 7 januari $2020^{30}$ dat de verwijzing van de arbeidsongeschiktheidsverzekeraar naar uitsluitend zijn eigen acceptatiebeleid tekortschoot. In dat geval dient verzekeraar

27. Zie in dit verband ook Wervelman 2019; M.L. Hendrikse \& J.G.J. Rinkens, 'Het uitgangspunt van de redelijk handelend verzekeraar in de regeling van art. 7:928-930 BW’, NTHR 2018, afl. 6, p. 290-292.

28. Hof Den Haag 18 augustus 2020, ECLI:NL:GHDHA:2020:1404, $J A$ 2020/139, m.nt. EJW.

29. HR 5 oktober 2018, ECLI:NL:HR:2018:1841, NJ 2020/69, m.nt. S. Lindenbergh.

30. Geschillencommissie Kifid 7 januari 2020, 2020-24 
immers aan te tonen dat verzekerde bij het aangaan van de verzekering wist of behoorde te begrijpen welk acceptatiebeleid verzekeraar hanteerde. Dat had de verzekeraar niet aangetoond. $^{31}$

De verzekeraar die ontdekt dat de mededelingsplicht niet is nagekomen, dient de verzekeringnemer daarvan overigens binnen twee maanden na de ontdekking in kennis te stellen (art. 7:929 lid 1 BW). Dat ging mis in de casus die leidde tot het arrest van het gerechtshof Arnhem-Leeuwarden van 26 maart 2019.32 De arbeidsongeschiktheidsverzekeraar beriep zich tegenover de curator in het faillissement van de besloten vennootschappen op verzwijging, maar had dat aldus tegenover de verzekeringnemer zelf moeten doen. Het beroep op verzwijging werd dan ook verworpen. ${ }^{33}$

\section{Arbeidsongeschiktheid}

$\mathrm{Om}$ in aanmerking te komen voor een uitkering krachtens een arbeidsongeschiktheidsverzekering is vereist dat sprake is van 'arbeidsongeschiktheid'. Doorgaans is arbeidsongeschiktheid gedefinieerd als de situatie waarvan uitsluitend sprake is indien er in relatie tot ziekte of ongeval objectief medisch vast te stellen stoornissen bestaan waardoor de verzekerde beperkt is in zijn functioneren. De normaal geïnformeerde en redelijk omzichtige en oplettende gemiddelde verzekerde moet redelijkerwijs begrijpen dat lichamelijke klachten moeten kunnen worden herleid tot een ziektebeeld, aldus het gerechtshof Amsterdam bij arrest van 26 februari 2019. ${ }^{34}$ Volgens het hof is voor het aannemen van dekking niet voldoende dat de verzekerde klachten ervaart en dat dat door de beoordelende arts als reëel wordt ervaren, terwijl hij de klachten op zijn vakgebied niet kan verklaren. Een redelijke uitleg van de polisvoorwaarden brengt naar vaste rechtspraak met zich mee dat ingeval sprake is van een herkenbaar en benoembaar ziektebeeld waarvan de oorzaak onbekend is, ook kan worden gesproken van een medisch vaststelbare stoornis gerelateerd aan ziekte. Daarvan was echter geen sprake in de casus die leidde tot dat arrest. De Hoge Raad verwierp het cassatieberoep tegen dit oordeel bij arrest van 10 juli 2020 op de voet van artikel 81 Wet RO. ${ }^{35}$

Ook in de casus die leidde tot het arrest van de Hoge Raad van 6 november $2020^{36}$ was geen sprake van arbeidsongeschiktheid in de zin van de toepasselijke polisvoorwaarden, nu de beoordelende artsen de klachten op hun vakgebied niet konden verklaren. Dit ondanks dat sprake was van reëel overko-

31. Zie omtrent de redelijk handelend verzekeraar ook Geschillencommissie Kifid 6 december 2019, 2019-1008.

32. Hof Arnhem-Leeuwarden 26 maart 2019, ECLI:NL:GHARL: 2019:2663.

33. Zie omtrent de redelijk handelend verzekeraar ook Hof Amsterdam 20 augustus 2019, ECLI:NL:GHAMS:2019:3065, JA 2019/151, m.nt. EJW.

34. Hof Amsterdam 26 februari 2019, ECLI:NL:GHAMS:2019:623. Vgl. HvJ EU 23 april 2015, ECLI:EU:C:2015:262 (Van Hove).

35. HR 10 juli 2020, ECLI:NL:HR:2020:1268.

36. HR 6 november 2020, ECLI:NL:HR:2020:1736, in cassatie op: Hof Amsterdam 19 februari 2019, ECLI:NL:GHAMS:2019:482. mende klachten, maar dus niet van duidelijk objectiveerbare afwijkingen die de klachten konden verklaren. Hiermee is aldus bij particuliere arbeidsongeschiktheidsverzekeringen echt sprake van een geheel ander toetsingskader dan bij letselschade. ${ }^{37}$

De polisvoorwaarde waarin 'arbeidsongeschiktheid' is neergelegd, vormt overigens een kernbeding. Het begrip 'arbeidsongeschiktheid' omschrijft wat in het kader van de verzekering onder arbeidsongeschiktheid wordt verstaan en daarmee wat de omvang van de dekking is. Daarmee is dus de verbintenis van de verzekeraar omschreven en afgebakend. Deze afbakening vindt ontegenzeggelijk haar weerslag in de hoogte van de premie, aldus het gerechtshof Amsterdam in zijn arrest van 19 februari $2019 .{ }^{38}$ Het hof overwoog daarbij dat uit de tekst van het beding helder volgt dat voor dekking noodzakelijk is dat sprake is van een medisch objectiveerbare stoornis die in relatie staat tot ziekte, en de verzekerde redelijkerwijs moest begrijpen dat lichamelijke klachten moeten kunnen worden herleid tot een ziektebeeld. Aldus achtte het hof het beding voldoende begrijpelijk. 'Arbeidsongeschiktheid' is volgens het hof een ruim begrip; het staat een verzekeraar vrij om te bepalen wat hij in dat verband wel en niet wenst te verzekeren. ${ }^{39}$

De Geschillencommissie van het Kifid volgt de opvatting van de civiele rechter. Dat is een rode draad in de jurisprudentie van het Kifid. ${ }^{40}$ In de uitspraak van de Geschillencommissie van het Kifid van 9 januari 2020 (2020-035) waren als psychiatrische aandoeningen uitsluitend gedekt psychotische stoornissen, bipolaire stoornissen en angst- en depressieve stoornissen. De autismespectrumstoornis (ASS), waarvan bij verzekerde sprake was, viel niet onder deze limitatieve opsomming en was dus niet krachtens de polis gedekt. ${ }^{41}$

\section{Claimbehandeling}

Er zijn veel actualiteiten rondom de claimbehandeling bij arbeidsongeschiktheidsverzekeringen. Met ingang van 1 juli 2020 geldt de Gedragscode Claimbehandeling 2020, die is opgesteld door het Verbond van Verzekeraars. Artikel 7 van

37. Vgl. ook E.J. Wervelman, De particuliere arbeidsongeschiktheidsverzekering, Deventer: Wolters Kluwer 2016, p. 254 e.v.

38. Hof Amsterdam 19 februari 2019, ECLI:NL:GHAMS:2019:482. De Hoge Raad verwierp het cassatieberoep dat tegen dit arrest werd ingesteld bij arrest van 6 november 2020, ECLI:NL:HR:2020:1736. Zie in gelijke zin Hof Amsterdam 26 februari 2019, ECLI:NL:GHAMS:2019:623. De Hoge Raad verwierp het cassatieberoep tegen dit arrest bij arrest van 10 juli 2020, ECLI:NL:HR:2020:1268.

39. Zie voor krachtens de polis gedekte spierproblematiek Rb. Amsterdam 20 maart 2019, ECLI:NL:RBAMS:2019:1882

40. Vgl. Geschillencommissie Kifid 20 mei 2020, 2020-437; Geschillencommissie Kifid 29 april 2020, 2020-350; Geschillencommissie Kifid 8 april 2020, 2020-318; Geschillencommissie Kifid 3 maart 2020, 2020-199; Geschillencommissie Kifid 25 februari 2020, 2020-159; Geschillencommissie Kifid 19 september 2019, 2019-709; Geschillencommissie Kifid 23 oktober 2019, 2019-831.

41. Zie voor toepassing van de 'normaal geïnformeerde en redelijk oplettende consument' ook Hof 's-Hertogenbosch 28 januari 2020, ECLI:NL: GHSHE:2020:250. 
deze gedragscode bevat een specifieke regeling voor aanbieders van individuele arbeidsongeschiktheidsverzekeringen. De Gedragscode Claimbehandeling 2020 vervangt voor wat betreft arbeidsongeschiktheidsverzekeringen het Protocol bij claims op Individuele Arbeidsongeschiktheidsverzekeringen uit 2016 van het Verbond van Verzekeraars. Dit protocol heeft recent veel aandacht gekregen door het arrest dat de Hoge Raad wees op 28 september $2018 .^{42}$ In dit arrest beantwoordt de Hoge Raad prejudiciële vragen van de rechtbank Den Haag. ${ }^{43}$ Inzet van de vragen vormde het beding dat de arbeidsongeschiktheidsverzekeraar de deskundigen benoemt naar aanleiding van een claim en aan de hand van diens bevindingen de mate van arbeidsongeschiktheid vaststelt. Dit beding komt in alle arbeidsongeschiktheidsverzekeringen voor en heeft tot uitvoerige discussie geleid over het antwoord op de vraag of het beding oneerlijk is. De Hoge Raad meent van niet. Daarbij wijst hij erop dat de procedure die is beschreven in het Protocol bij claims op Individuele Arbeidsongeschiktheidsverzekeringen uit 2016 leidt tot een standpuntbepaling van de verzekeraar. En niet meer dan dat. Verzekerde kan tegen dat standpunt bezwaar maken binnen dertig dagen. Deze termijn had volgens de Hoge Raad geen ander doel dan het bevorderen van een voortvarende afhandeling van de claim. Een sanctie was daaraan niet verbonden. In die zin heeft het beding volgens de Hoge Raad dus geen betekenis voor de rechtspositie van de verzekerde. Daarom is het beding ook niet oneerlijk. Evenmin is sprake van een aanzienlijke verstoring van het evenwicht tussen partijen. Dat is (ook) een van de essentiële elementen om te kunnen spreken van een oneerlijk beding. De Hoge Raad onderzoekt daartoe wat tussen partijen zou hebben gegolden indien geen regeling zou zijn getroffen. Welnu, dan geldt artikel 7:941 lid 2 BW. Daarin is bepaald dat de verzekeringnemer en de tot uitkering gerechtigde verplicht zijn om binnen redelijke termijn de verzekeraar alle inlichtingen en bescheiden te verschaffen die voor deze van belang zijn om zijn uitkeringsplicht te beoordelen. Dat kan met zich brengen dat de verzekerde moet meewerken aan een door de verzekeraar wenselijk geacht onderzoek. Komt hij die wettelijke verplichting niet na, dan kan de verzekeraar daar onder omstandigheden sancties aan verbinden (art. 7:941 lid 3 en 4 BW). Dat betekent volgens de Hoge Raad dat het verschil in rechtspositie daarin bestaat dat er een rapport ligt dat op kosten van de verzekeraar tot stand is gekomen, waarbij verzekerde geen aanspraak heeft kunnen maken op inspraak bij de keuze van de persoon van de deskundige en de aan die te stellen vragen. Het beding weggedacht, levert dat de verzekerde een voordeel op, omdat hij de kosten anders voor eigen rekening zou moeten nemen. Het nadeel voor de verzekerde is dat hij geen invloed heeft kunnen uitoefenen op de totstandkoming van het rapport voor wat betreft de keuze van de persoon en de onderzoeksvragen. Het gaat echter om een partijrapport. Verzekerde kan dat met eigen onderzoek betwisten, aldus de Hoge Raad, die erop wijst dat de bezwaren in een

42. HR 28 september 2018, ECLI:NL:HR:2018:1800, NJ 2020/68, m.nt S.D. Lindenbergh.

43. Rb. Den Haag 15 november 2017, ECLI:NL:RBDHA:2017:16419. klacht of een gerechtelijke procedure moeten worden gewogen. Bovendien relativeert de Hoge Raad het gebrek aan inspraak door erop te wijzen dat de verzekerde wettelijk gehouden is om zijn medewerking te verlenen aan een door de verzekeraar gewenst onderzoek. ${ }^{44}$ Het arrest van de Hoge Raad is bekritiseerd in de literatuur. ${ }^{45} \mathrm{Nu}$ de kern van deze kritiek vooral ligt in een deugdelijke contractuele contraexpertise, wijs ik erop dat deze inmiddels in de meeste arbeidsongeschiktheidsverzekeringen is verankerd. Voorts is deze regeling nader uitgewerkt in de artikelen 7.6-7.8 van de Gedragscode Claimbehandeling 2020 van het Verbond van Verzekeraars. ${ }^{46}$

Doorgaans zijn bij de behandeling van claims krachtens arbeidsongeschiktheidsverzekeringen drie disciplines betrokken. Het gaat om (1) de medisch specialist die vaststelt of bij verzekerde sprake is van objectief medisch vast te stellen stoornissen in directe relatie tot ziekte of ongeval, en daarnaast om (2) de verzekeringsarts die op basis van de door de medisch specialist vastgestelde stoornis(sen) en eigen onderzoek vaststelt in hoeverre er bij verzekerde sprake is van beperkingen voor arbeidswerkzaamheden. Ten slotte (3) maakt de arbeidsdeskundige op basis van deze beperkingen in een eigen onderzoek een inschatting van de mate waarin verzekerde de werkzaamheden in zijn of haar beroep of in passende arbeid niet meer kan verrichten. ${ }^{47}$

Veel arbeidsongeschiktheidsverzekeringen bepalen dat ter vaststelling van de mate van arbeidsongeschiktheid (tevens) rekening wordt gehouden met taakaanpassingen en/of taakverschuivingen, dan wel met aanpassingen van werkomstandigheden binnen het eigen beroep of bedrijf die in redelijkheid van de verzekerde kunnen worden verlangd. Een dergelijke polisvoorwaarde heet de 'taakverschuivingsclausule'. Deze makt deel uit van het begrip 'arbeidsongeschiktheid'. In sommige gevallen wordt de taakverschuivingsclausule van toepassing na een jaar arbeidsongeschiktheid. De toepassing van deze clausule kan grote gevolgen hebben voor de mate van arbeidsongeschiktheid. Temeer daar het gaat om een theoretische duiding. Toch zijn er grenzen. Een voorbeeld daarvan is te vinden in de casus die leidde tot het arrest van het gerechtshof

44. Vgl. over dit arrest ook E.J. Wervelman, 'De benoeming van deskundigen bij arbeidsongeschiktheidsverzekeringen: geen oneerlijk beding; HR 28 september 2018', NTHR 2019, afl. 1, p. 10-17; E.J. Wervelman, Oneerlijke bedingen: de AOV-praktijk (preadvies Vereniging voor Verzekeringswetenschap), Deventer: Wolters Kluwer 2019.

45. Vgl. H.B. Krans, 'Een oordeel over een beding in polisvoorwaarden: een ongelukkige uitkomst', NTBR 2019/10; W.M. van Boom, annotatie bij HR 28 september 2018, ECLI:NL:HR:2018:1800, AA 2020, p. 60-69.

46. Zie omtrent een en ander ook E.J. Wervelman, 'Kroniek van de particuliere arbeidsongeschiktheidsverzekering 2014-2019 (Deel II)', $A V \& S$ 2019/32 (hierna: Wervelman 2019b).

47. Vgl. bijv. Hof Arnhem-Leeuwarden 30 augustus 2016, ECLI:NL:GHARL:2016:6941. Zie voorts E.J. Wervelman, 'De particuliere arbeidsongeschiktheidsverzekering', in: M.L. Hendrikse, Ph.H.J.G. van Huizen \& J.G.J. Rinkes (red.), Verzekeringsrecht, Deventer: Wolters Kluwer 2019, p. 1016. 
Arnhem-Leeuwarden van 28 januari 2020. ${ }^{48}$ De arbeidsdeskundige beoordeling sloot op 50\% arbeidsongeschiktheid voor de beroepsuitoefening. De arbeidsdeskundige constateerde echter dat de inzetbaarheid van verzekerde 5 uur per dag was bij een zesdaagse werkweek. Met een reistijd van 2,2 uur per dag resteerde er slechts 2,8 uur voor werk op de locatie. Deze resterende inzet achtte de arbeidsdeskundige te gering om het eigen beroep/de eigen werkzaamheden naar behoren te verrichten. Nog daargelaten dat het eigen bedrijf van verzekerde niet meer bestond. Het hof was dan ook, met de arbeidsdeskundige, van oordeel dat vanuit arbeidsdeskundig oogpunt moet worden uitgegaan van volledige arbeidsongeschiktheid. Het hof tekende daarbij nog aan dat de taakverschuivingsclausule daar geen verandering in bracht. Met de opsomming van de theoretische mogelijkheden verloor de verzekeraar volgens het hof uit het oog dat verzekerde al negen jaar geen eigen bedrijf meer had. Dat bedrijf bestond dus feitelijk ook al heel lang niet meer. Bovendien was gesteld noch gebleken dat verzekerde in staat moest worden geacht om op 59-jarige leeftijd een soortgelijk, nieuw bedrijf uit te oefenen met inachtneming van taakverschuivingen met een (nieuwe) compagnon. En, zo vervolgt het hof, zo er nog wel sprake zou zijn geweest van het bedrijf van verzekerde, dan achtte de arbeidsdeskundige de resterende inzetbaarheid ook te gering om de eigen werkzaamheden naar behoren te kunnen verrichten. ${ }^{49}$

Arbeidsongeschiktheid dient zo spoedig mogelijk aan de verzekeraar te worden gemeld. Doorgaans bepalen de polisvoorwaarden tevens dat overschrijding van de in de polis neergelegde termijn verval van recht op uitkering tot gevolg heeft. Dat is alleen anders indien de verzekeraar niet in zijn belangen is geschaad. Te late melding van arbeidsongeschiktheid komt met enige regelmaat voor. Dat speelde ook in de casus die leidde tot het arrest van het gerechtshof Amsterdam van 4 maart $2020 .{ }^{50}$ Verzekerde meldde zich in januari 2015 arbeidsongeschikt bij verzekeraar met ingang van 12 december 2012. Verzekeraar had volgens het hof gemotiveerd aangevoerd dat hij door de te late melding is belemmerd in zijn mogelijkheden zelfstandig onderzoek te doen naar de aard, oorzaak en omvang van de arbeidsongeschiktheid die met ingang van 12 december 2012 zou hebben bestaan. Bij gebreke van informatie heeft hij niet kunnen vaststellen of verzekerde in het eerste jaar na 12 december 2012 volledig arbeidsongeschikt was als gevolg van ziekte of ongeval, wat voorwaarde is voor dekking. Het lag volgens het hof vervolgens op de weg van verzekerde om zo veel mogelijk gemotiveerd te stellen dat en waarom verzekeraar door de te late melding niet in een

48. Hof Arnhem-Leeuwarden 28 januari 2020, ECLI:NL:GHARL: 2020:745.

49. Zie omtrent takverschuivingsclausules ook Wervelman $2019 \mathrm{~b}$ en de aldaar besproken jurisprudentie. Zie ook Hof Arnhem-Leeuwarden 16 april 2019, ECLI:NL:GHARL:2019:3349.

50. Hof Amsterdam 4 maart 2020, ECLI:NL:GHAMS:2020:934. Vgl. voor een geslaagd beroep op te late melding door de verzekeraar ook Geschillencommissie Kifid 24 juli 2018, 2018-459; E.J. Wervelman, De particuliere arbeidsongeschiktheidsverzekering (diss. Rotterdam), Deventer: Wolters Kluwer 2016, par. 4.2.6. redelijk belang is geschaad. Zo had hij concreet kunnen maken, bijvoorbeeld aan de hand van medische stukken en gegevens die hem ter beschikking staan, of anderszins, dat het bestaan van zijn (volledige) arbeidsongeschiktheid alsnog kan worden vastgesteld, zodat het beroep op verval van dekking dient te worden gepasseerd. Als uit de benodigde gegevens namelijk toch de arbeidsongeschiktheid komt vast te staan en verzekeraar derhalve door het niet kunnen uitvoeren van zijn onderzoek niet daadwerkelijk is benadeeld, behoort het vervallen van de uitkering achterwege te blijven. Het zou te ver gaan om van de verzekeraar te vergen dat hij stelt en zo nodig ook bewijst dat de benodigde gegevens niet langs andere weg kunnen worden verkregen, aldus nog steeds het hof. Het is immers aan de verzekerde te wijten dat de verzekeraar de benodigde gegevens niet heeft kunnen verzamelen op de reguliere wijze van een schadevaststelling en toedrachtonderzoek naar aanleiding van een onverwijlde melding en correcte verstrekking van inlichtingen. Verzekerde had in de processtukken en ter zitting de aard, omvang en oorzaak van zijn arbeidsongeschiktheid niet concreet toegelicht of aan de hand van stukken onderbouwd. Hij heeft dit ook niet gedaan door te verwijzen naar bepaalde passages in de overgelegde medische stukken. Verzekerde had daarmee in reactie op het beroep op schending van de belangen van verzekeraar niet voldoende aanknopingspunten verschaft om te kunnen aannemen dat hij in het eerste jaar na 12 december 2012 volledig arbeidsongeschikt was ten gevolge van ziekte of ongeval. Evenmin had hij aangevoerd dat en hoe het alsnog mogelijk was om dat vast te stellen, aldus het hof. Het beroep van verzekeraar op het vervalbeding werd dan ook toegewezen.

Verzekerden dienen de arbeidsongeschiktheid niet alleen zo spoedig mogelijk bij de verzekeraar te melden, maar ook alle inlichtingen en bescheiden te verschaffen die voor de verzekeraar van belang zijn om de arbeidsongeschiktheid en het recht op uitkering te beoordelen. Deze verplichting is doorgaans contractueel verankerd in de polisvoorwaarden. Daarnaast is deze verankerd in de wet. Bij opzet tot misleiding bepalen zowel de polisvoorwaarden als de wet in artikel 7:941 lid 5 BW dat het recht op uitkering vervalt. De Hoge Raad heeft dit recent bevestigd bij arrest van 21 februari 2020, ${ }^{51}$ waarin hij overweegt dat het er daarbij om gaat of de verzekeringnemer of de tot uitkering gerechtigde het opzet heeft gehad om de verzekeraar te misleiden. Daarbij dient te worden onderzocht of hij hierbij de bedoeling heeft gehad de verzekeraar te bewegen tot het verstrekken van een uitkering die hij zonder die schending niet zou hebben verstrekt. Bij het beoordelen in het kader van de uitkeringsplicht in hoeverre de verzekerde beperkt is om de werkzaamheden die zijn verbonden aan het beroep uit te oefenen, is evident dat ten aanzien van die beperkingen (zo veel mogelijk) helderheid moet worden gegeven. Verzekerde dient de verzekeraar daarom een zo volledig mogelijk beeld te geven van hetgeen waartoe hij in staat was en hij in dat kader ondernam. Ook als sprake is van een sommen-

51. HR 21 februari 2020, ECLI:NL:HR:2020:311. 
verzekering. Tussen partijen stond als onbestreden in cassatie vast dat de verzekeraar de mogelijkheid was ontnomen om onderzoek te doen naar de uitbreiding van de werkzaamheden begin 2013. Deze uitbreiding had de verzekerde niet gemeld. De verzekeraar was daardoor de mogelijkheid ontnomen om daar onderzoek naar te doen, met mogelijke consequenties voor zijn bewijspositie in een later stadium. Daarom was de verzekeraar in een redelijk belang geschaad als bedoeld in artikel 7:941 lid 4 BW. ${ }^{52}$

\section{Afsluiting}

Er zijn veel actualiteiten rondom arbeidsongeschiktheidsverzekeringen. In het oog springend is met name het arrest van de Hoge Raad van 28 september $2018,{ }^{53}$ dat ziet op de polisvoorwaarde die strekt tot benoeming van deskundigen door verzekeraars. Ondanks de kritiek op het arrest in de literatuur bevat het een duidelijke vingerwijzing voor de praktijk. Om met Hartlief te spreken moest de branche 'de handschoen oppakken'. Welnu, dat heeft de branche inmiddels gedaan met de invoering van de Gedragscode Claimbehandeling 2020, die is opgesteld door het Verbond van Verzekeraars. Deze Gedragscode is in werking getreden met ingang van 1 juli 2020 en bevat in artikel 7 een specifieke regeling voor de claimbehandeling van arbeidsongeschiktheidsverzekeringen. Daarnaast bevatten de meeste polisvoorwaarden inmiddels een secondopinionregeling. Ook dat vormt aldus een uitwerking van de kanttekeningen van de Hoge Raad. Ik maak mij sterk dat deze ontwikkelingen de rechtszekerheid - en daarmee de claimbehandeling van arbeidsongeschiktheidsverzekeringen - ten goede zullen komen. Dat zie ik eerlijk gezegd als winst: de branche moet verzekerden immers bieden waarvoor (arbeidsongeschiktheids)verzekeringen (in essentie) zijn bedoeld: zekerheid.

52. Vgl. omtrent opzet tot misleiding ook GiEA Curaçao 18 mei 2020 , ECLI:NL:OGEAC:2020:127; Rb. Gelderland 12 februari 2020, ECLI:NL:RBGEL:2020:1132; Commissie van Beroep Kifid 27 november 2019, 2019-42 en 43; HR 25 oktober 2019, ECLI:NL:HR 2019:163; Rb. Midden-Nederland 18 oktober 2019, ECLI:NL:RBMNE: 2019:6494; Wervelman 2019b.

53. HR 28 september 2018, ECLI:NL:HR:2018:1800, NJ 2020/68 m.nt. S.D. Lindenbergh. 